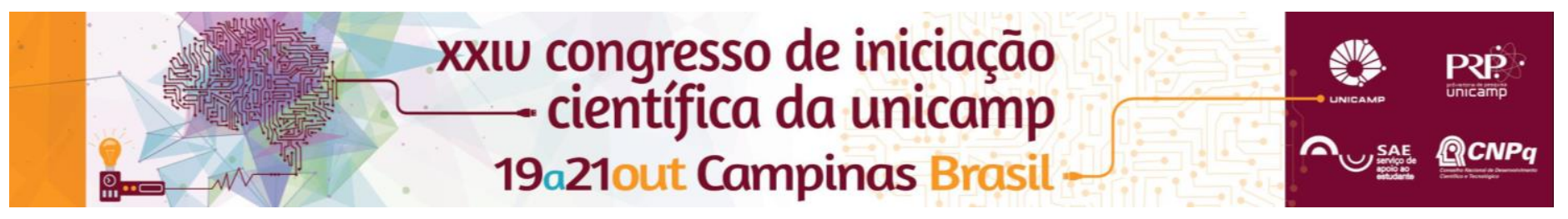

\title{
As políticas climáticas da cidade de São Paulo
}

\section{Fernando Medeiros}

\section{Resumo}

Tem-se por finalidade conhecer a maneira como a questão das mudanças climáticas foi abordada e como o governo da cidade de São Paulo lidou com ela, em medidas de ações, como leis e programas do governo municipal.

\section{Palavras-chave}

Política, Clima, São Paulo

\section{Introdução}

As últimas projeções sobre as mudanças ambientais globais que podem ocorrer nas próximas décadas tem associado o estilo de vida nas chamadas megacidades como um fator fundamental a ser considerado nesse processo, contribuindo, por exemplo, para a rapidez das mudanças climáticas no mundo. $O$ (IPCC), Painel Intergovernamental sobre Mudanças Climáticas, da Organização das Nações Unidas considera que há $95 \%$ de probabilidade de que os as mudanças climáticas poderão afetar decisivamente os ambientes urbanos e causar impactos na vida das pessoas. O fato é que resolver problemas atuais e futuros, principalmente associado às mudanças no clima, se torna um enorme desafio nas megacidades. É com base nessa discussão inicial apresentada que a pesquisa objetiva apresentar como se estruturou as políticas de combate às mudanças climáticas na cidade de São Paulo, compilando as principais respostas institucionais apresentadas nessa cidade (2009-2015), para enfrentar os diferentes desafios surgidos em função do conjunto de problemas que compõe a agenda das mudanças ambientais.

\section{Resultados e Discussão}

Após realizar um mapeamento geral da Lei $\mathrm{N}^{\circ}$ 14.933/09 -política de mudança do Clima no Município de São Paulo- que criou uma agenda para as políticas com o tema das mudanças climáticas para o município de São Paulo, também foram realizadas pesquisas sobre artigos científicos, de autores que já falassem sobre a importância dessa Lei, e também sobre as políticas realizadas pelo governo. Os objetivos da lei eram tornar estáveis as concentrações de gases de efeito estufa, em prazo razoável para permitir aos ecossistemas adaptação natural à mudança do clima e permitir o desenvolvimento econômico de maneira sustentável. Também nesse sentido, em 2011, o governo de São Paulo (Secretaria do Verde e do Meio Ambiente) assinou uma Carta de Intenções com o governo do Estado (Secretaria de Energia) visando a adoção de energias renováveis.

Todavia no final de 2012, a meta estipulada diminuição de $30 \%$ das emissões -pela Lei $N^{\circ} 14.933 / 09$ não alcançou seus objetivos. O Inventário Municipal de Emissões e Remoções Antrópicas de Gases de Efeito Estufa de 2003 a 2009, com atualização para o ano de 2010 e 2011 nos setores de Energia e Resíduos, apresentado no ano de 2012 pela prefeitura, mostra que, além de não alcançar o objetivo, a cidade aumentou a emissão de gases em 2010 e 2011.
Tabela 1. Fontes de emissão de GEE, riscos ambientais e seus impactos

\begin{tabular}{|c|c|c|c|}
\hline & $\begin{array}{l}\text { Principal } \\
\text { Fonte de } \\
\text { Emissão } \\
\text { de GEE }\end{array}$ & $\begin{array}{l}\text { Principal } \\
\text { risco } \\
\text { ambiental }\end{array}$ & $\begin{array}{c}\text { Principais } \\
\text { impactos para a } \\
\text { população }\end{array}$ \\
\hline $\begin{array}{c}\text { São } \\
\text { Paulo }\end{array}$ & $\begin{array}{l}\text { Frota de } \\
\text { veículos }\end{array}$ & $\begin{array}{l}\text { Chuvas } \\
\text { intensas }\end{array}$ & $\begin{array}{l}\text { Enchentes, } \\
\text { inundações, } \\
\text { alagamentos e } \\
\text { enxurradas; } \\
>\text { Afogamentos e } \\
\text { ferimentos; } \\
>\text { Transmissão } \\
\text { de doenças } \\
\text { pela água; } \\
>\text { Deslizamentos } \\
\text { em encostas; } \\
\text { Deslocamentos } \\
\text { Dabitacionais; } \\
\text { h } \text { Mortalidade. }\end{array}$ \\
\hline
\end{tabular}

\section{Conclusões}

A Aprovação da "Lei do Clima" (Lei №13.933/09) em São Paulo é pioneira, trouxe importantes ações por parte do governo municipal. Além de ações como o Decreto Municipal №50.866, que propõe acompanhar, fiscalizar e propor ações que viabilizem o cumprimento da Lei $N^{\circ} 13.933$. No ano de 2010, foram criados 6 grupos de trabalho, os grupos ficaram responsáveis pela condução das políticas públicas do Governo Municipal com relação às mudanças climáticas. Mas, é possível concluir que as estruturas existentes e as alternativas que vêm sendo propostas até o momento ainda são insuficientes, entretanto, frente à complexidade do problema, a avaliação sobre as ações do Governo municipal de São Paulo pareceu ser razoável.

\section{Agradecimentos}

Ao Conselho Nacional de Desenvolvimento Científico e Tecnológico (CNPq); à Prof $\stackrel{a}{\text { a }}$ Dr $^{\mathrm{a}}$. Leila da Costa Ferreira, pela orientação e oportunidade; à Alberto Matenhauer Urbinatti,; à minha família e amigos.

BECK, U. Risk Society. Beverly Hills: Sage, 1992. 